\title{
Effect of extrusion of rapeseed oilmeal on rumen degradability and intestinal digestibility ${ }^{1}$
}

\author{
S. Michalak and A. Potkański \\ The August Cieszkowski Agricultural University of Poznań, \\ Department of Animal Nutrition and Feed Management \\ Wotyńska 33, 60-637 Poznań, Poland
}

\begin{abstract}
Effective ruminal protein degradation (EPD) and the intestinal digestibility of undegraded protein (IUPD) of rapeseed oilmeal (RSM) subjected to extrusion at a temperature of $140^{\circ} \mathrm{C}$ was determined. The protein EPD coefficient of the extruded rapeseed oilmeal (ERSM) was 55.5\%, whereas that of the RSM not subjected to extrusion, 79.3\%. The intestinal digestibility of rumenundegraded RSM protein was $55.5 \%$, which was 38.3 percentage points lower than the IUPD of the ERSM. The total tract protein digestibility of both meals was similar. The high IUPD of the ERSM indicates a favourable shift of protein availability from the rumen to further sections of the gastrointestinal tract.
\end{abstract}

KEY WORDS: rapeseed oilmeal, protein, ruminal degradation, intestinal digestibility

\section{INTRODUCTION}

The principal factor limiting the value of extracted rapeseed oilmeal (RSM) in the nutrition of high yielding cows is the excessive sensitivity of nitrogen compounds to ruminal degradation. The degradation coefficient of RSM protein ranges from 62 to 77\% (Madsen and Hvelplund, 1985; Żebrowska et al., 1997). Extrusion could be beneficial for feed protein utilization and for this reason the experiment was carried out to determine protein disappearance from the rumen and post-ruminal part of the digestive tract from untreated (RSM) or extruded (ESRM) rapeseed oilmeal.

\footnotetext{
1* Supported by the State Committee for Scientific Research, Grant No. 5 PO6E 01219 Corresponding author: e-mail: potkansk@jay.au.poznan.pl
} 


\section{MATERIAL AND METHODS}

The experiments were conducted on two Jersey heifers of $435 \mathrm{~kg}$ body weight fitted with ruminal and duodenal cannulas and fed standard diets. The RSM was extruded at $140^{\circ} \mathrm{C}$ using a single-worm extruder (Insta-Pro ${ }^{\circledR} 2000 \mathrm{R}$ Company). Crude protein degradation in the rumen was determined by the in sacco method described by Kowalski et al. (2001), while the intestinal digestibility of rumenundegraded protein was assessed using the mobile bag method (Hvelplund and Weisbjerg, 2000). The ruminal degradation constants of crude protein were calculated from the Ørskov and McDonald (1979) equation with the PROC NLIN (SAS, 1996) calculation procedure. The intestinal digestibility of rumenundegraded dietary protein (IUPD) and the total tract protein digestibility (TTPD) were calculated according to the formulas described by Kowalski et al. (1997).

\section{RESULTS}

The experiment in sacco confirmed a significant influence of extrusion on the reduction of crude protein losses in the rumen in the particular periods of incubation. Differences between feeds were particularly noticeable between the 4 and $8 \mathrm{~h}$ of incubation (Figure 1).

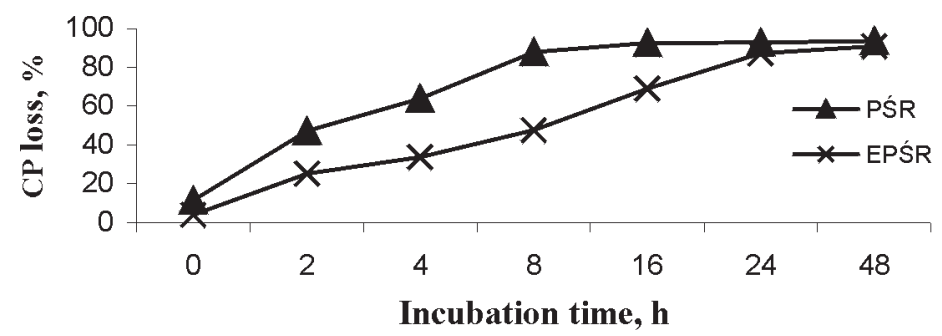

Figure 1. Losses of crude protein (CP) in consecutive hours of incubation, $\%$

The degradation parameters and EPD coefficients of crude protein presented in Table 1 show a lower constant $a$ and higher $b$ value for ERSM than for RSM. Moreover, the extrusion process dramatically reduced EPD of rapeseed oilmeal.

The intestinal digestibility of RSM protein undegraded in the rumen was lower than of ERSM protein by about 38 percentage points, but protein digestibility in the total tract (TTPD) was similar for untreated and treated rapeseed oilmeal. 
Table 1. Protein degradability parameters (a, b, c), effective ruminal protein degradation (EPD), intestinal digestibility of rumen-undegraded protein (IUPD) and total tract protein digestibility (TTPD) of RSM and ERSM

\begin{tabular}{lcc}
\hline Degradation constants & RSM & ERSM \\
\hline A & 11.22 & 9.76 \\
B & 82.78 & 87.04 \\
C & 0.28 & 0.07 \\
EPD & 79.25 & 55.54 \\
IUPD & 55.5 & 93.8 \\
TTPD & 96.1 & 98.1 \\
\hline
\end{tabular}

\section{DISCUSSION}

The results of the experiment demonstrated that the extrusion of RSM decreased the susceptibility of its protein to rumen degradability, but the protein undigested in the rumen protein was more intensively digested further in the digestive tract, giving in effect similar values of total-tract protein digestibility. The effect of the distal shift of protein digestion from the rumen is desirable as decomposition of protein in the rumen to ammonia is avoided and amino acids of rumen-undegraded protein can be utilized more effectively by their absorption from the intestine.

The similar loss of RSM and ERSM protein in the rumen after $24 \mathrm{~h}$ of incubation could suggest ineffective protection of protein by extrusion, but the calculated retention time of the feed particles in the rumen is shorter, as at the passage rate of $\mathrm{k}=0.06$ it amounts to only $16 \mathrm{~h}$ (Ørskov and Mc Donald, 1979). This is the reason that rumen overpass of protein from ERSM is greater than from RSM. Similar trends following treatment of protein by different physical factors were also reported by other researchers (Tuori, 1992; Aufrère et al., 1998). Cros et al. (1991) also confirmed the effectiveness of the Insta-Pro ${ }^{\circledR}$ method for the protection of protein. The use of a double-worm extruder to protect the protein of whole field beans (Benchaar et al., 1994) and pea (Walhain et al., 1992) also increased the amino acid pool available in the intestines.

\section{CONCLUSIONS}

Extrusion of rapeseed oilmeal at $140^{\circ} \mathrm{C}$ shifts protein digestion from the rumen to the intestines, which can be beneficial for protein utilization. 


\section{REFERENCES}

Aufrère J., Graviou D., Demarquilly C., 1998. The significance of the degradation products of rapeseed meal proteins in the rumen according to different meal processing techniques. Ann. Zootech. 47, 127-140

Benchaar C., Vernay M., Bayourthe C., Moncoulon R., 1994. Effects of extrusion of whole horse beans on protein digestion and amino acid absorption in dairy cows. J. Dairy Sci. 77, 1360-1371

Cros P., Benchaar C., Bayourthe C., Vernay M., Moncoulon R., 1991. In situ evaluation of the ruminal and intestinal degradability of extruded whole lupin seed nitrogen. Reprod. Nutr. Develop. 31, 575-583

Hvelplund T., Weisbjerg M.R., 2000. In situ techniques for estimation of protein degradabililty and postrumen availability. In: D.I. Givens, E. Owen, R.F.E. Axford, H.M. Omed (Editiors). Forage Evaluation in Ruminant Nutrition. CABI Publishing, Wallingford, pp. 233-258

Kowalski Z.M., Marszałek A., Mills C., 1997. The use of Ca salts of rapeseed fatty acids to protect protein against degradation in the rumen. Anim. Feed Sci. Tech. 65, 265-274

Kowalski Z.M., Niwińska B., Nowak W., Pająk J., Szyszkowska A., 2001. Standard nylon bag in situ method for estimation of feed protein degradability in the rumen (in Polish). Editor: Collective for Ruminant Nutrition, National Research Institute of Animal Production, Kraków (Poland)

Madsen J., Hvelplund T., 1985. Protein degradation in the rumen. Acta Agr. Scand., Suppl. 25, 103-124

Ørskov E.R., McDonald I., 1979. The estimation of protein degradability in the rumen from incubation measurements weighted according to rate of passage. J. Agr. Sci. 92, 499-503

Tuori M., 1992. Rapeseed meal as a supplementary protein for dairy cows on grass silage-based diet with the emphasis on the Nordic AAT-PBV feed protein evaluation system. Agr. Sci. Finland 1, 367-439

Walhain P., Foucart M., Théwis A., 1992. Influence of extrusion on ruminal and intestinal disappearance in sacco of pea (Pisum sativum) proteins and starch. Anim. Feed Sci. Tech. 38, 43-55

Żebrowska T., Długołęcka Z., Pająk J.J., Korczyński W., 1997. Rumen degradability of concentrate protein, amino acids and starch, and their digestibility in the small intestine of cows. J. Anim. Feed Sci. 6, 451-470

\section{STRESZCZENIE}

\section{Wpływ ekstruzji poekstrakcyjnej śruty rzepakowej na strawność białka w żwaczu i jelitach}

Oznaczono efektywny rozkład białka w żwaczu (EPD) oraz strawność jelitową białka nie strawionego w żwaczu (IUPD) poekstrakcyjnej śruty rzepakowej (RSM) poddanej ekstruzji w temperaturze $140^{\circ} \mathrm{C}$. Współczynnik EPD białka ekstruderatu (ERSM) wynosił 55,5\%, natomiast śruty nie poddanej ekstruzji 79,3\%. Strawność jelitowa (SJ) białka nie ulegającego rozkładowi w żwaczu RSM wynosiła 55,5\% i była niższa od SJ ERSM o 38,3 punktu procentowego. Strawność białka obydwóch śrut w całym przewodzie pokarmowym była podobna. Wysoka IUPD białka extrudowanej śruty wskazuje na korzystne przesunięcie dostępności białka ze żwacza do dalszych odcinków przewodu pokarmowego. 